\title{
MOSSES OF KALUGA PROVINCE (MIDDLE EUROPEAN RUSSIA) AND THEIR REPRODUCTIVE FEATURES
}

\section{ЛИСТОСТЕБЕЛЬНЫЕ МХИ КАЛУЖСКОЙ ОБЛАСТИ (СРЕДНЯЯ ПОЛОСА ЕВРОПЕЙСКОЙ РОССИИ) И ОСОБЕННОСТИ ИХ РЕПРОДУКТИВНОЙ БИОЛОГИИ}

\author{
V.V. TELEGANOVA ${ }^{1}$ \\ B.В. ТЕЛЕГАНОВА ${ }^{1}$
}

\begin{abstract}
Moss flora of Kaluga Province includes 226 species, 42 of them were found for the fist time in the province. The annotated list provides the data on the distribution and habitat preference of species. The proportion of sexes and the frequency of sporophytes and gametangia for monoicous and dioicous species is analyzed.
\end{abstract}

Резюме

Флора листостебельных мхов Калужской области включает 226 видов, из них 42 вида являются новыми для области. Приводится конспект флоры с указанием встречаемости, местонахождений и экологической приуроченности видов. Проанализировано соотношение полов, частота спороношения и образования гаметангиев у видов с разными половыми типами.

\section{STUDY AREA AND ITS EXPLORATION}

Kaluga Province is situated in the Central European Russia, in a lowland. Its area is $29,900 \mathrm{sq}$. $\mathrm{km}$, and $44 \%$ of the territory is covered by forest, the hemiboreal type in the north, and the broadleaved one in the south. The virgin forests are almost lacking, while secondary Betula forests are the most widespread. Arable lands cover extensive areas, especially in the central and eastern parts of the province. Peatlands are rare, less than $1 \%$ of the province territory, occurring mostly in the western, more forested part (Pashkang, 1989).

The moss collections from the province are known since 1910s (few collections in LE), and publications appeared since 1920. Zhadovsky (1928) listed 22 species for Chertovo Gorodishche, an interesting place with sandstone outcrops; this list includes a number of very rare species. Simultaneously, in the course of peatland studies, Gerasimov (1924) and Rabotnov (1929) reported several mire species, including some never found after that. After about half of the century, Peshkova (1975) published a list of Sphagna of the northwestern part of the province and also a short list (32 species) of mosses collected near the town of Tarusa. Her main collection of mosses remains unpublished, but it had been granted to the Herbarium of Moscow University (MW) and was used in the present study. Later, mosses were collected by Majorov (2001) in Kozelsky District and by Smirnova in the Nature Reserve «Kaluzhskie Zaseki» in Ulyanovsk District. The latter collection has been studied by Popova, who also made her own exploration in Kozelsk, Ulyanovsk and Khvastovichi Districts (Popova \& Ob'edkova, 2000; Popova, 2001, 2002). Altogether, 180 species have been reported from the province in all these publications.

My studies in recent years, 2006-2008, revealed 42 species new to the province and I col-

1 - National Park «Ugra», Russia, 248007, Kaluga, Prigorodnoe lesnichestvo - Национальный парк «Угра», Россия, 248007, Калуга, пос. Пригородное лесничество 
Fig. 1. Collecting localities of mosses in Kaluga Province. See also Table 1.

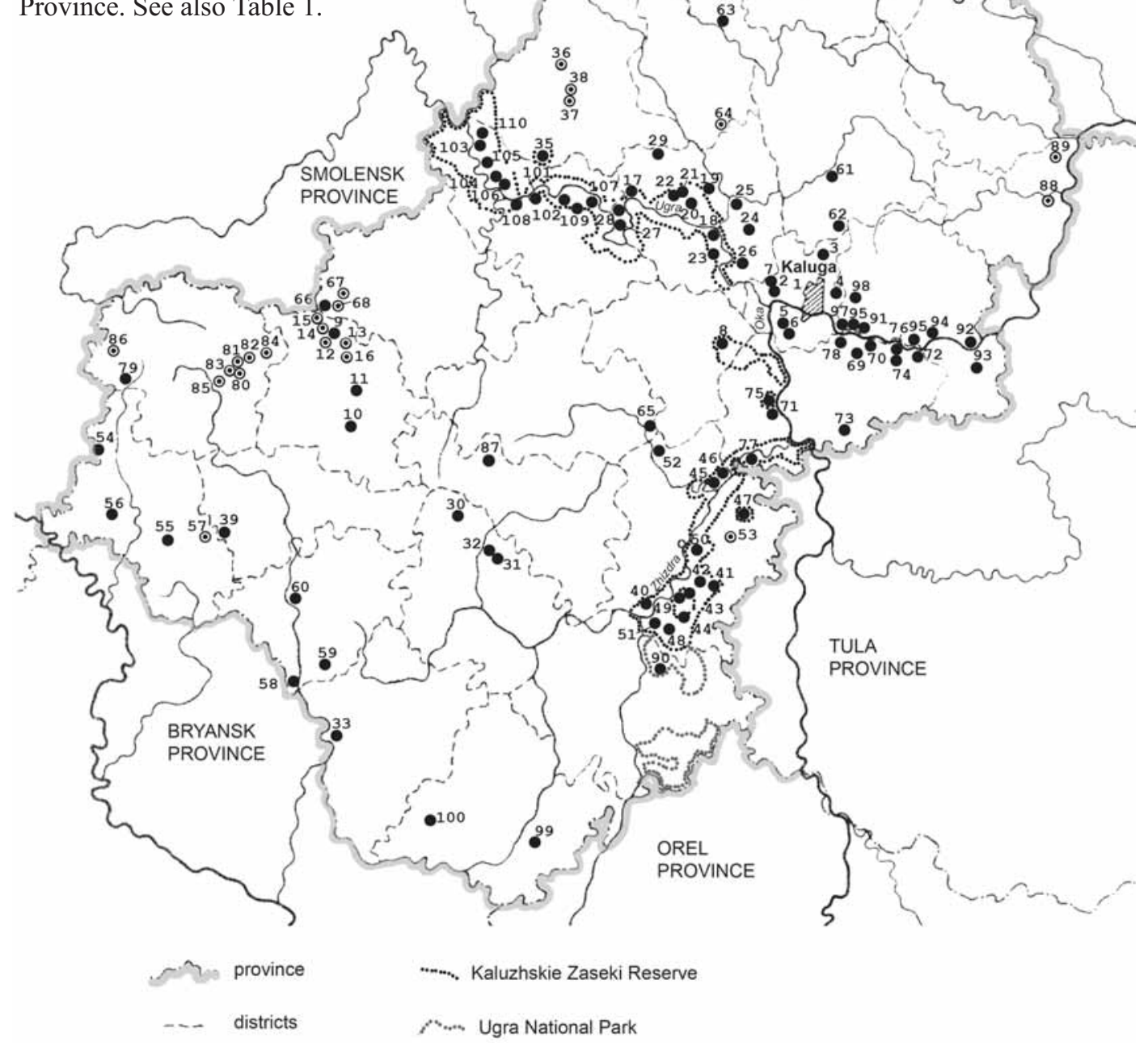

Table 1. List of localities shown in Fig. 1.

№ местонахождение

1. г. Калуга: Калужский городской бор

2. бор за мкр. Аненки

3. заброшенный известняковый карьер в окр. ж/д ст. Садовая

4. окр. пос. Ждамирово

5. пойменный широколиственный лес к Ю-3 д. Чижовка

6. ельники в окр. дд. Сивково и Верх. Вырка

7. заброшенный известняковый карьер в окр. пос. Мстихино

8. Бабынинский р-н: склоны к р. Выссе locality

Kaluga: Kaluga City pine forest pine forest near Anenki abandoned lime-pit near Sadovaya railway station Zhdamirovo

flood-plain broad-leaved forest

S-W of Chizhovka

$54^{\circ} 27^{\prime} \mathrm{N}-36^{\circ} 07^{\prime} \mathrm{E}$

$54^{\circ} 25^{\prime} \mathrm{N}-36^{\circ} 10^{\prime} \mathrm{E}$ and Verkhnyaya Vyrka abandoned lime-pit near Mstikhino $54^{\circ} 34^{\prime} \mathrm{N}-36^{\circ} 06^{\prime} \mathrm{E}$

Latitude - Longitude

$54^{\circ} 31^{\prime} \mathrm{N}-36^{\circ} 13^{\prime} \mathrm{E}$

$54^{\circ} 32^{\prime} \mathrm{N}-36^{\circ} 09^{\prime} \mathrm{E}$

$54^{\circ} 33^{\prime} \mathrm{N}-36^{\circ} 14^{\prime} \mathrm{E}$

$54^{\circ} 31^{\prime} \mathrm{N}-36^{\circ} 23^{\prime} \mathrm{E}$

Babyninsky Distr:: slopes to Vyssa River 
в окр. дд. Кромино и Шамордино

9. Барятинский р-н: Шатино болото (зарастающие торфоразработки)

10. окр. с. Зеваки Белозерские

11. окр. с. Крисаново-Пятница

12. д. Зимницы

13. д. Глазово

14. д. Калугово

15. пос. Калуговское болото

16. д. Красниково

17. Дзержинский p-н: 17. склоны к р. Угре у дд. Звизжи и Никола-Ленивец

18. склоны к р. Угре напротив пос. Товарково

19. выработанный торфяник и лес вокруг него в окр. д. Шеняно-Слобода

20. ур. Бурцево

21. Галкинское болото

22. Бучкино болото

23. выработанный торфяник в окр. с. Горбенки

24. зарастающие отвалы известняковых карьеров у пос. Акатово

25. зарастающие отвалы известняковых карьеров у пос. Полотняный Завод

26. сосняки в окр. пос. Льва Толстого

27. склоны к р. Угре в окр. д. Смагино

28. с сфагновое болото у д. Дюкино

29. болото и лес вокруг него у д. Копоня

30. Думиничский p-н: смешанные леса в окр. д. Верх. Сяглово

31. смешанные леса к В д. Шваново

32. ольшаники у вдхр. Брынь

33. Жиздринский р-н: хвойные и пойменные широколиственные леса в окр. с. Улемль

34. Жуковский р-н: д. Воробьи

35. Износковский р-н: Морозовское болото

36. д. Ефаново

37. д. Сигово

38. д. Даниловка

39. Кировский $\mathrm{p}-\mathrm{H}:$ водораздельный широколиственный лес к С-3 д. Засецкий

40. Козельский р-н: хвойные и пойменные широколиственные леса в окр. с. Волконско

41. боры на дюнах на правобережье p. Жиздры к С пос. Слаговищи near Kromino and Shamordino

$54^{\circ} 25-26^{\prime} \mathrm{N}-35^{\circ} 58-59^{\prime} \mathrm{E}$

Baryatinsky Distr.: Shatino Bog

(overgroving drained bog)

$54^{\circ} 29^{\prime} \mathrm{N}-34^{\circ} 29^{\prime} \mathrm{E}$

Zevaki Belozerskie

$54^{\circ} 17^{\prime} \mathrm{N}-34^{\circ} 36^{\prime} \mathrm{E}$

Krisanovo-Pyatnitsa

$54^{\circ} 32^{\prime} \mathrm{N}-34^{\circ} 38^{\prime} \mathrm{E}$

Zimnitsy

$54^{\circ} 26^{\prime} \mathrm{N}-34^{\circ} 28^{\prime} \mathrm{E}$

Glazovo

Kalugovo

$54^{\circ} 27^{\prime} \mathrm{N}-34^{\circ} 38^{\prime} \mathrm{E}$

$54^{\circ} 29^{\prime} \mathrm{N}-34^{\circ} 29^{\prime} \mathrm{E}$

Kalugovo Bog

$54^{\circ} 32^{\prime} \mathrm{N}-34^{\circ} 27^{\prime} \mathrm{E}$

Krasnikovo

$54^{\circ} 23^{\prime} \mathrm{N}-34^{\circ} 33^{\prime} \mathrm{E}$

Dzerzhinsky Distr.: slopes to Ugra River near Zvizzhi and Nikola-Lenivets $54^{\circ} 44^{\prime} \mathrm{N}-35^{\circ} 37^{\prime} \mathrm{E}$ slopes to Ugra River

opposite Tovarkovo

$54^{\circ} 40^{\prime} \mathrm{N}-35^{\circ} 55^{\prime} \mathrm{E}$

drained peatbog and forest around it

near Shenyano-Sloboda

$54^{\circ} 44^{\prime} \mathrm{N}-35^{\circ} 56^{\prime} \mathrm{E}$

Burtsevo

Galkino Bog

$54^{\circ} 42^{\prime} \mathrm{N}-35^{\circ} 51^{\prime} \mathrm{E}$

Buchkino Bog

$54^{\circ} 45^{\prime} \mathrm{N}-35^{\circ} 49^{\prime} \mathrm{E}$

drained peatbog near Gorbenki

$54^{\circ} 45^{\prime} \mathrm{N}-35^{\circ} 48^{\prime} \mathrm{E}$

overgrowing dumps of abandoned

lime-pits near Akatovo

$54^{\circ} 41^{\prime} \mathrm{N}-36^{\circ} 02^{\prime} \mathrm{E}$

overgrowing dumps of abandoned

lime-pits near Polotnyanyi Zavod $54^{\circ} 43^{\prime} \mathrm{N}-35^{\circ} 58^{\prime} \mathrm{E}$

pine forests near L'va Tolstogo $\quad 54^{\circ} 35^{\prime} \mathrm{N}-36^{\circ} 00^{\prime} \mathrm{E}$ slopes to Ugra River near Smagino $54^{\circ} 41^{\prime} \mathrm{N}-35^{\circ} 34^{\prime} \mathrm{E}$

Sphagnum bog near Dyukino $\quad 54^{\circ} 43^{\prime} \mathrm{N}-35^{\circ} 32^{\prime} \mathrm{E}$

mire and forest around it

near Koponya

$53^{\circ} 52^{\prime} \mathrm{N}-35^{\circ} 50^{\prime} \mathrm{E}$

Duminichsky Distr.: mixed forests

near Verkhnee Syaglovo

$54^{\circ} 05^{\prime} \mathrm{N}-34^{\circ} 59^{\prime} \mathrm{E}$

mixed forests E of Shvanovo

$54^{\circ} 03^{\prime} \mathrm{N}-35^{\circ} 05^{\prime} \mathrm{E}$ alder forest near Bryn' water reservoir $54^{\circ} 03^{\prime} \mathrm{N}-35^{\circ} 05^{\prime} \mathrm{E}$

Zhizdrinsky Distr.: coniferous and flood-plain

broad-leaf forests near Uleml" $\quad 53^{\circ} 39^{\prime} \mathrm{N}-34^{\circ} 30^{\prime} \mathrm{E}$

Zhukovsky Distr.: Vorob'i $\quad 55^{\circ} 09^{\prime} \mathrm{N}-36^{\circ} 49^{\prime} \mathrm{E}$

Iznoskovsky Distr.: Morozovo Bog $54^{\circ} 49^{\prime} \mathrm{N}-35^{\circ} 16^{\prime} \mathrm{E}$

Efanovo

$55^{\circ} 00^{\prime} \mathrm{N}-35^{\circ} 18^{\prime} \mathrm{E}$

Sigovo

$54^{\circ} 54^{\prime} \mathrm{N}-35^{\circ} 23^{\prime} \mathrm{E}$

Danilovka

$54^{\circ} 57^{\prime} \mathrm{N}-35^{\circ} 20^{\prime} \mathrm{E}$

Kirovsky Distr.: watershed broad-leaved

forest N-W of Zasetsky

$54^{\circ} 03^{\prime} \mathrm{N}-34^{\circ} 06^{\prime} \mathrm{E}$

Kozelsky Distr.: coniferous and flood-plain broad-leaved forests near Volkonskoe

$53^{\circ} 54^{\prime} \mathrm{N}-35^{\circ} 40^{\prime} \mathrm{E}$

pine forests on sand-hills on right bank

of Zhizdra River N of Slagovischi $53^{\circ} 58^{\prime} \mathrm{N}-35^{\circ} 41^{\prime} \mathrm{E}$ 
Table 1. List of localities shown in Fig. 1 (continued).

42. окр. пос. Березичский Стеклозавод

43. склоны к р. Чепчик

44. водораздельные широколиственные леса к 3 д. Волосово-Звягино

45. склоны к р. Серене у д. Каменка

46. склоны к р. Жиздре у дд. Подборки и Верх. Алопово

47. ур. Чертово Городище

48. елово-широколиственные леса к 3 д. Трошна

49. окр. экологической базы «Отрада»

50. зарастающие торфоразработки у пос. Механический Завод

51. сфагновое болото и лес вокруг него к 3 д. Кричина

52. склоны к р. Серене у д Сбелево

53. окр. пос. Сосенский

54. Куйбышевский р-н: окр. д. Орловка

55. окр. пос. Бетлица

56. ур. Ковалевская дача

57. ж/д. ст. Феликсово

58. Людиновский р-н: окр. д. Куява

59. окр.д. Моисеевка

60. ур. Красный воин

61. Малоярославецкий р-н: Природный парк «Остров» у пос. Детчино

62. заброшенная усадьба у д. Дубровка

63. Медынский р-н: склоны к р. Лужа у д. Кременское

64. д. Желтыкино

65. Мещовский р-н: склоны к р. Серене у дд. Сбежня и Копцево

66. Мосальский р-н: окр. оз. Бездон

67. д. Долгое

68. д. Нов. Калугово

69. Перемышльский р-н: склоны к р. Ужердь к Ю от с. Ахлебинино

70. склоны к р. Оке у с. Ахлебинино

71. склоны к р. Птаре у дд. Ладыгино и Ершовка

72. склоны к р. Оке у д. Брагино

73. склоны к р. Свободь у д. Красниково

74. окр. д. Семеновка
Berezichsky Steklozavod

$53^{\circ} 56^{\prime} \mathrm{N}-35^{\circ} 48^{\prime} \mathrm{E}$

slopes to Chepchik Creek

$53^{\circ} 56^{\prime} \mathrm{N}-35^{\circ} 48^{\prime} \mathrm{E}$

watershed broad-leaf forest $\mathrm{W}$ of

Volosovo-Zvyagino

$54^{\circ} 50^{\prime} \mathrm{N}-35^{\circ} 48^{\prime} \mathrm{E}$

slopes to Serena River near Kamenka $54^{\circ} 09^{\prime} \mathrm{N}-35^{\circ} 53^{\prime} \mathrm{E}$

slopes to Zhizdra River near Podborki

and Verkh. Alopovo

$54^{\circ} 11^{\prime} \mathrm{N}-35^{\circ} 57^{\prime} \mathrm{E}$

Chertovo Gorodische

$54^{\circ} 05^{\prime} \mathrm{N}-36^{\circ} 00^{\prime} \mathrm{E}$

spruce-broad-leaf forests

$\mathrm{W}$ of Troshna

$53^{\circ} 51^{\prime} \mathrm{N}-35^{\circ} 46^{\prime} \mathrm{E}$

ecological station "Otrada"

$53^{\circ} 55^{\prime} \mathrm{N}-35^{\circ} 45^{\prime} \mathrm{E}$

overgroving drained peatbog

near Mekhanichesky Zavod

$54^{\circ} 00^{\prime} \mathrm{N}-35^{\circ} 50^{\prime} \mathrm{E}$

Sphagnum bog and forest around it

W of Krichina

$53^{\circ} 50^{\prime} \mathrm{N}-35^{\circ} 40^{\prime} \mathrm{E}$

slopes to Serena River near Sbelevo $54^{\circ} 13^{\prime} \mathrm{N}-35^{\circ} 39^{\prime} \mathrm{E}$

Sosensky

$54^{\circ} 02^{\prime} \mathrm{N}-35^{\circ} 58^{\prime} \mathrm{E}$

Kuibyshevsky Distr.: Orlovka

$54^{\circ} 20^{\prime} \mathrm{N}-33^{\circ} 29^{\prime} \mathrm{E}$

Betlitsa

$54^{\circ} 01^{\prime} \mathrm{N}-33^{\circ} 57^{\prime} \mathrm{E}$

Kovalevskaya dacha

$54^{\circ} 05^{\prime} \mathrm{N}-33^{\circ} 43^{\prime} \mathrm{E}$

railway station Feliksovo

$54^{\circ} 03^{\prime} \mathrm{N}-34^{\circ} 06^{\prime} \mathrm{E}$

Ludinovsky Distr.: Kuyava

$53^{\circ} 44^{\prime} \mathrm{N}-34^{\circ} 24^{\prime} \mathrm{E}$

Moiseevka

$53^{\circ} 46^{\prime} \mathrm{N}-34^{\circ} 35^{\prime} \mathrm{E}$

Krasnyi Voin

$53^{\circ} 55^{\prime} \mathrm{N}-34^{\circ} 21^{\prime} \mathrm{E}$

Maloyaroslavetsky Distr.: Nature Park

"Ostrov" near Detchino

$54^{\circ} 48^{\prime} \mathrm{N}-36^{\circ} 19^{\prime} \mathrm{E}$

abandoned country estate

near Dubrovka

$54^{\circ} 43^{\prime} \mathrm{N}-36^{\circ} 20^{\prime} \mathrm{E}$

Medynsky Distr.: slopes to Luzha River

near Kremenskoe

$55^{\circ} 06^{\prime} \mathrm{N}-35^{\circ} 57^{\prime} \mathrm{E}$

Zheltykino

$54^{\circ} 52^{\prime} \mathrm{N}-35^{\circ} 55^{\prime} \mathrm{E}$

Meschosky Distr.: slopes to Serena River

near Sbezhnya and Koptsevo $\quad 54^{\circ} 15^{\prime} \mathrm{N}-35^{\circ} 39^{\prime} \mathrm{E}$

Mosalsky Distr.: Bezdon Lake $\quad 54^{\circ} 30^{\prime} \mathrm{N}-34^{\circ} 26^{\prime} \mathrm{E}$

Dolgoe

$54^{\circ} 33^{\prime} \mathrm{N}-34^{\circ} 34^{\prime} \mathrm{E}$

Novoe Kalugovo

$54^{\circ} 32^{\prime} \mathrm{N}-34^{\circ} 29^{\prime} \mathrm{E}$

Peremyshlsky Distr:: slopes to Uzherd River

$\mathrm{S}$ of Akhlebinino

$54^{\circ} 25^{\prime} \mathrm{N}-36^{\circ} 25^{\prime} \mathrm{E}$

slopes to Oka River near Akhlebinino $54^{\circ} 26^{\prime} \mathrm{N}-36^{\circ} 26^{\prime} \mathrm{E}$

slopes to Ptara River near

Ladygino and Ershovka

$54^{\circ} 19^{\prime} \mathrm{N}-36^{\circ} 05^{\prime} \mathrm{E}$

slopes to Oka River near Bragino $54^{\circ} 25^{\prime} \mathrm{N}-36^{\circ} 39^{\prime} \mathrm{E}$

slopes to Svobod River near

Krasnikovo

$54^{\circ} 15^{\prime} \mathrm{N}-36^{\circ} 23^{\prime} \mathrm{E}$

Semenovka

$54^{\circ} 25^{\prime} \mathrm{N}-36^{\circ} 35^{\prime} \mathrm{E}$ 
75. склоны к оз. Тишь у д. Желохово

76. склоны к р. Оке у д. Пески

77. сфагновое болото и склоны к р. Жиздре у с. Ильинское

78. окр. д. Крутицы

79. Спас-Деменский р-н: окр. д. Церковщина

80. болото Игнатовский Мох

81. д. Князево

82. ст. Чипляево

83. д. Утриково

84. д. Суходол

85. д. Лесково

86. д. Нестеры

87. Сухиничский р-н: окр. д. Володино

88. Тарусский р-н: окр. г. Тарусы

89. окр. с. Некрасово

90. Ульяновский р-н: окр. д. Новая Деревня (ГПЗ “Калужские Засеки”)

91. Ферзиковский р-н: склоны к р. Оке у д. Авчурино

92. склоны к р. Оке напротив с. Дугна

93. окр. д. Широково

94. заброшенный известняковый карьер и склоны к р. Оке к В с. Кольцово

95. скллоны к р. Оке у д. Криуши

96. «Кольцовские пещеры» (выходы известняков на склоне к р Оке у д. Михайловка)

97. склоны к р. Оке в окр. пос. Турынино

98. окр. д. Красотынка

99. Хвастовичский р-н: боры на дюнах в окр. с. Теребень

100. окр. д. Слобода

101. Юхновский р-н: Юхновский бор, г. Юхнов

102. склоны к р. Угре у д. Палатки

103. ур. Косая гора

104. Беляевское болото

105. хвойные и смешанные леса от д. Беляево до ур. Косая гора

106. ельник у д. Беляево

107. склоны к р. Угре в окр. д. Олоньи горы

108. сложный бор к С от д. Натальинка

109. сплавина озера и лес вокруг него у д. Озерки

110. Пановское болото slopes to Tish' Lake near Zhelokhovo54 $21^{\prime} \mathrm{N}-36^{\circ} 09^{\prime} \mathrm{E}$ slopes to Oka River near Peski $\quad 54^{\circ} 25^{\prime} \mathrm{N}-36^{\circ} 37^{\prime} \mathrm{E}$

Sphagnum mire and slopes to Zhizdra River

near Il'inskoe $\quad 54^{\circ} 12^{\prime} \mathrm{N}-36^{\circ} 03^{\prime} \mathrm{E}$

Krutitsy $\quad 54^{\circ} 27^{\prime} \mathrm{N}-36^{\circ} 21^{\prime} \mathrm{E}$

Spas-Demensky Distr:: Tserkovschina $54^{\circ} 22^{\prime} \mathrm{N}-33^{\circ} 42^{\prime} \mathrm{E}$

Ignatovo Bog $\quad 54^{\circ} 21^{\prime} \mathrm{N}-34^{\circ} 11^{\prime} \mathrm{E}$

Knyazeve $\quad 54^{\circ} 23^{\prime} \mathrm{N}-34^{\circ} 09^{\prime} \mathrm{E}$

Chiplyaevo $\quad 54^{\circ} 23^{\prime} \mathrm{N}-34^{\circ} 12^{\prime} \mathrm{E}$

Utrikovo $\quad 54^{\circ} 21^{\prime} \mathrm{N}-34^{\circ} 07^{\prime} \mathrm{E}$

Sukhodol $54^{\circ} 24-34^{\circ} 15^{\prime} \mathrm{E}$

Leskovo $\quad 54^{\circ} 20-34^{\circ} 00^{\prime} \mathrm{E}$

Nestery $\quad 54^{\circ} 25-33^{\circ} 42^{\prime} \mathrm{E}$

Sukhinichsky Distr.: Volodino $\quad 54^{\circ} 13-35^{\circ} 05^{\prime} \mathrm{E}$

Tarussky Distr.: Tarusa $\quad 54^{\circ} 43-37^{\circ} 01^{\prime} \mathrm{E}$

Nekrasovo $\quad 54^{\circ} 49-37^{\circ} 08^{\prime} \mathrm{E}$

Ul'yanovsky Distr.: Novaya Derevnya

(Kaluzhskie Zaseki Reserve) $\quad 53^{\circ} 47^{\prime} \mathrm{N}-35^{\circ} 44^{\prime} \mathrm{E}$

Ferzikovsky Distr.: slopes to Oka River

near Avchurino $\quad 54^{\circ} 27^{\prime} \mathrm{N}-36^{\circ} 25$

slopes to Oka River opposite Dugna $54^{\circ} 26^{\prime} \mathrm{N}-36^{\circ} 52$

Shirokovo

$54^{\circ} 23^{\prime} \mathrm{N}-36^{\circ} 49^{\prime} \mathrm{E}$

abandoned lime-pit and slopes to Oka River

E of Kol'tsovo $\quad 54^{\circ} 26^{\prime} \mathrm{N}-36^{\circ} 43^{\prime} \mathrm{E}$

slopes to Oka river near Kriushi $\quad 54^{\circ} 27^{\prime} \mathrm{N}-36^{\circ} 22^{\prime} \mathrm{E}$

"Koltsovo caves" (limestone outcrops on the slopes to Oka River near Mikhailovka) $\quad 54^{\circ} 25^{\prime} \mathrm{N}-36^{\circ} 36^{\prime} \mathrm{E}$

slopes to Oka river near Turynino $54^{\circ} 30^{\prime} \mathrm{N}-36^{\circ} 22^{\prime} \mathrm{E}$

Krasotynka

$54^{\circ} 31^{\prime} \mathrm{N}-36^{\circ} 24^{\prime} \mathrm{E}$

Khvastovichsky Distr.: pine forests

on sand-hills near Tereben' $\quad 53^{\circ} 25^{\prime} \mathrm{N}-35^{\circ} 18^{\prime} \mathrm{E}$

Sloboda

$53^{\circ} 28^{\prime} \mathrm{N}-34^{\circ} 51^{\prime} \mathrm{E}$

pine forest

$54^{\circ} 45^{\prime} \mathrm{N}-35^{\circ} 20^{\prime} \mathrm{E}$

slopes to Ugra river near Palatki $54^{\circ} 45^{\prime} \mathrm{N}-35^{\circ} 21^{\prime} \mathrm{E}$

Kosaya gora

$54^{\circ} 51^{\prime} \mathrm{N}-35^{\circ} 03^{\prime} \mathrm{E}$

Belyaevo Bog

$54^{\circ} 47^{\prime} \mathrm{N}-35^{\circ} 06^{\prime} \mathrm{E}$

coniferous and mixed forests

from Belyaevo to Kosaya gora $\quad 54^{\circ} 50^{\prime} \mathrm{N}-35^{\circ} 04^{\prime} \mathrm{E}$

spruce forest near Belyaevo $\quad 54^{\circ} 47^{\prime} \mathrm{N}-35^{\circ} 06^{\prime} \mathrm{E}$

slopes to Ugra River near Olon'I gory $54^{\circ} 43^{\prime} \mathrm{N}-35^{\circ} 28^{\prime} \mathrm{E}$

pine forest $\mathrm{N}$ of Natal'inka $\quad 54^{\circ} 45^{\prime} \mathrm{N}-35^{\circ} 20^{\prime} \mathrm{E}$

mire around Ozerki Lake

and forest around it

$54^{\circ} 44^{\prime} \mathrm{N}-35^{\circ} 23^{\prime} \mathrm{E}$

Panovo Bog 
lected additional data for the characteristics of species distribution in 110 localities (Fig. 1, Table 1). The exploration was focused especially on the river valleys, where slopes often have oldgrowth forest and limestone outcrops. Another type of habitats of special interest was peatlands. Some interesting findings have been published before (Teleganova et al., 2008; Teleganova \& Ignatov, 2006; Teleganova, 2007).

In addition to overall species distribuition, the second aim of the study was an evaluation of the presence of gametangia and sporophytes. These data were collected mainly for 35 dioicous species with rare sporophyte production. This study was based on a number of samples from all studied localities. For other species such data were not collected specially in the field, but they were included in the course of preparation of the paper basing on the re-study of available herbarium collections even if a relatively few number of specimens were available for the count. We believe that the observed proportion of sexes and the frequency of sporophytes can at least give a general impression on the frequency of sexes and sporophyte production in the province.

\section{LIST OF SPECIES}

The list includes 226 species. The occurrence is abbreviated as $\mathrm{U}$ - unique (one locality, even if found in several places within it), $\mathrm{R}$ - rare (2-7), $\mathrm{S}-$ sporadic (8-30), $\mathrm{C}-$ common (usually $>30$, but widespread and locally abundant species, like Amblystegium serpens and Aulacomnium palustre, were referred to common even if the number of specially studied localities where they were found was smaller). Some common and well-recognizable species were not collected from all the studied places, thus some of them are under-represented in herbarium collections. Their occurrence was evaluated using both herbarium and field records. After that, the localities are listed, using numbers explained in Table 1 and Fig. 1); literature records are given before enumeration of localities studied by myself. They are followed by brief data on species ecology, and then the sex distribution is given as follow: for dioicous species abbreviations include: $f$ - number of female collections, $\mathrm{m}-$ male collections, fmS- - mixed collections without sporophytes, $\mathrm{fmS}+-$ mixed collections with sporophytes, st - sterile); the oc- currence of sporophytes and sterile condition is indicated for autoicous species (S-, S+). For Sphagna, the presence/absence of sporophytes was registered irrespectively to their sexual condition. The differential occurrences of sexes on different substrates is indicated where this was noticed. Dioicous species that were in a special focus of this study are indicated by asterisk (*).

Voucher specimens are in KLH, most duplicates in MHA.

*Abietinella abietina (Hedw.) M.Fleisch. - C; [1, 8, $17,18,24,25,26,27,33,40,41,42,43,52,58,60$, $61,63,65,70,71,76,91,92,93,94,99,100]$; in open dry places: edges of pine forests, steppe, dry meadows, on soil-covered rock outcrops, concrete blocks, also recorded on the aspen trunk base in a flood-plane forest [26f; $12 \mathrm{~m} ; 2 \mathrm{fmS}-; 2 \mathrm{fmS}+; 5 \mathrm{st}$ ]. Sporophytes were found for the first time in the middle part of European Russia, and probably in the whole Russia.

Aloina rigida (Hedw.) Limpr. - U; [7]; on limestone in a limestone pit $[1 \mathrm{~S}+]$.

Amblystegium serpens (Hedw.) Bruch et al. - C; [17, $18,24,44,45,63,70,72,73,76,91,92,94,95,97$, $102,103,105]$; on rocks, soil, rotten wood and tree trunk bases [30S+ (on all types of substrates), 3S-].

*Anomodon attenuatus (Hedw.) Huebener - S; [Kaluzhskie Zaseki Reserve (Popova, 2002); 47 (Zhadovsky, 1928; Popova, 2002); 5, 33, 40, 44, 46, $48,49,52,58,60,70,72,76,91,92,94,96,97$, 107]; broad-leaved forests; on tree trunks and soilcovered rock outcrops [26f; $10 \mathrm{~m} ; 2 \mathrm{fmS}-; 2 \mathrm{fmS}+$; $15 \mathrm{st}]$. Male and mixed populations, as well as sporophytes were found only on trunks.

*A. longifolius (Brid.) Hartm. $-\mathrm{S}$; [Kaluzhskie Zaseki Reserve, 47 (Popova, 2002); 88 (Peshkova, 1977); $5,18,33,39,44,46,47,48,52,56,58,60,62,66$, $70,72,73,76,92,94,95,96,97,90,99,107]$; broadleaved forests; on tree trunks and soil-covered rock outcrops [29f; 29m (on tree trunks more often); $28 \mathrm{fmS}+; 5 \mathrm{st}]$.

*A. viticulosus (Hedw.) Hook. - S; [47 (Popova, 2002); $18,33,39,40,44,58,60,70,72,76,92,96,97]$; broad-leaved forests; on tree trunks and soil-covered rock outcrops [4f; $12 \mathrm{~m} ; 16 \mathrm{fmS}+$; 9st].

Atrichum tenellum (Röhl.) Bruch et al. - R; [47, 53 (Popova, 2002) and 2 other localities (Popova, 2001); $44,58,61]$; on bare sandy soil on roadsides in forests, on soil-covered outcrop of sandstone [3st].

A. undulatum (Hedw.) P.Beauv. - C; [88, 89 (Peshkova, 1977); 1, 4, 5, 6, 8, 10, 11, 17, 19, 23, 27, 29, 30, $31,32,33,44,46,47,48,49,50,54,55,56,66,69$, $71,73,77,79,92,93,102,103,105,107,108]$; on bare soil and under upturned roots in forests, some- 
times in overgrowing meadows, opening, soil-covered rock outcrops [13S + (on all types of substrates); 5S-].

Aulacomnium palustre (Hedw.) Schwägr. - C; [1, 2, 9, $20,21,28,29,35,39,40,42,47,50,51,56,77,80$, 90, 100, 104]; Sphagnum bogs, on hummocks; boggy pine forests, on soil, sometimes on damp rotten wood $[2 \mathrm{fmS}+; 7 \mathrm{st}]$.

Barbula convoluta Hedw. - R; [72, 76]; on bare soil, soil-covered damp limestone [1f; 2st].

*B. unguiculata Hedw. - C; [1, 3, 4, 5, 6, 7, 8, 18, 24, $25,26,32,41,42,45,46,52,55,58,60,63,65,69$, $70,72,74,75,76,78,92,93,94,94,97]$; on bare soil and rocks in open habitats [3f; $17 \mathrm{fmS}+; 5 \mathrm{st}]$.

Brachyteciastrum velutinum (Hedw.) Ignatov \& Huttunen - C; $[5,17,18,30,33,42,49,60,66,70,91$, $92,97,99,105,106]$; on tree trunk bases, bare soil and rotten wood in forests, soil-covered rocks [13S+; 3S-].

* Brachythecium albicans (Hedw.) Bruch et al. - C; [5, $25,52,61,63,70,71,76,91,93,99,103]$; in dry open habitats: steppes, dry meadows, roadsides, grassy and herbaceous slopes [8f; 4m; 4st].

B. campestre (Müll.Hal.) Bruch et al. - S; [5, 17, 24, $40,42,48,60,63,70,99,103$ ]; similar to previous species, and also found in broad-leaved forest on rotten wood [3S+; 4S-].

B. glareosum (Bruch ex Spruce) Bruch et al. - R; [17, 65 ]; open grassy slopes to river valleys, on soil and dry limestones [3f].

B. mildeanum (Schimp.) Schimp. - S; [3, 17, 23, 42, $58,72,46,70,91,94]$; in wet and disturbed habitats, on soil [4S+; $5 \mathrm{~S}-]$.

* B. rivulare Bruch et al. - C; [53 (Popova, 2002); 3, 8, $9,17,27,40,46,49,52,58,63,65,72,79,90,94$, $96,97,102,108]$; wet habitats, mostly on soil and rocks on the banks of creeks [ $5 \mathrm{f} ; 7 \mathrm{~m} ; 14 \mathrm{fmS}+; 11 \mathrm{st}]$.

B. rotaeanum De Not. - R; $[8,44,72,73]$; on limestones and on the trunk of Ulmus in broad-leaved forest $[4 \mathrm{~S}+]$.

B. rutabulum (Hedw.) Bruch et al. - C; [17, 18, 24, 27, $31,33,39,42,44,45,47,48,49,56,58,60,62,65$, $69,70,71,72,92,93,94,95,103,105,106,107$, 108]; in wet and shady habitats: mostly on rotten wood and soil-covered rock outcrops in forests [29S+; 6S-].

B. salebrosum (F.Weber \& D.Mohr) Bruch et al. - C; $[1,3,4,6,8,17,18,24,25,27,31,39,44,46,49$, $60,62,69,70,72,74,77,92,94,95,97,103,105$, $108]$; on tree trunk bases, soil, rotten wood, soil-covered rocks [27S+;7S-].

Breidleria pratensis (W.D.J.Koch ex Spruce) LoeskeU; [9 (collection of Peshkova \& Bachurina, 1965, MW)]; drained overgrowing mire with hypnalean mosses, on soil.
Bryoerythrophyllum recurvirostrum (Hedw.) P.C.Chen - R; [46, 52, 76, 102]; on limestones and calcareous soil in open habitats, and on rotten wood near a spring [4S+; 1S-].

*Bryum argenteum Hedw. - C; [17, 18, 24, 42, 65, 73, 92, 97, 100]; in different habitats and on different substrates, including variously disturbed ones [3f; $3 \mathrm{fmS}+; 3 \mathrm{st}]$.

B. bimum (Schreb.) Turner - U; [82 (Peshkova, Bachurina, 1965 (MW)]; on soil in shrub stand.

B. caespiticium Hedw. - C; [88 (Peshkova, 1977); 5, $18,48,69,91,92,94,97,100,103]$; on bare sandy soil, often on disturbed and man-made substrates [1m; $5 \mathrm{fmS}+; 2 \mathrm{st}]$.

B. capillare Hedw. - C; [17, 54, 69, 70, 91, 97]; on soil, rotten wood, exserted roots of trees in forests [3m; 2st].

B. creberrimum Taylor-S; [47 (V.I. Zolotov's unpublished data); 63, 69, 103]; on bare sandy soil [4S+].

B. intermedium (Brid.) Blandow - U; [6 (Popova, 2002)]; on limestones in sunny place.

B. lonchocaulon Müll.Hal. -S; [3, 24, 45, 46, 75, 100]; on bare sandy soil, often in more or less open boggy habitats [5S+; 2S-].

*B. moravicum Podp.- S; [33, 42, 43, 48, 49, 60, 69, $72,73,77,97,92,95]$; on tree trunks and tree bases in forests, on soil-covered rock outcrops [1f; 15st].

B. pallens Sw. ex anon. - S; [Kaluzhskie Zaseki Reserve; 47 (Popova, 2002); 49, 58, 78]; on damp bare soil, often on bluff banks of rivers [1fmS $+; 2$ st].

B. pseudotriquetrum (Hedw.) P.Gaertn., B.Mey. \& Scherb. - C; [3, 9, 19, 23, 24, 42, 59, 65, 97, 103, 108]; on soil and rotten wood in wet habitats [1f; $10 \mathrm{st}]$.

B. weigelii Spreng. - U; [Kaluzhskie Zaseki Reserve (Popova, 2002)]; in wet habitats on soil.

Buxbaumia aphylla Hedw. - R; [47 (Popova, 2002); 53 (Majorov, 2001); 41, 99]; on sandy soil on banks of trenches in pine forests [ $2 \mathrm{fmS}+]$.

Callicladium haldanianum (Grev.) H.A. Crum. - C; $[17,33,42,44,46,47,49,50,58,60,70,76,90,92$, $95,97,103,105,108]$; on rotten wood and tree trunk bases in forests [17S+; 3S-].

Calliergon cordifolim (Hedw.) Kindb. - S; [47 (Popova, 2002); 3, 9, 17, 23, 33, 29, 42, 46, 50, 54, 55, 58, $79,87,90,99,105,110]$; on soil in swampy habitats [4S+ (meso- and eutrophic mires); 15S-].

C. giganteum (Schimp.) Kindb. - R; [Spas-Demensky Distr. (Rabotnov, 1929); 9]; drained overgrowing mire with hypnalean mosses, on soil [1st].

*Calliergonella cuspidata (Hedw.) Loeske - C; [3, 9, $17,18,19,25,42,43,45,46,49,53,92,94,100$, 103]; in wet, more or less open habitats, mostly on soil on wet meadows [ $5 \mathrm{f} ; 9 \mathrm{~m} ; 2 \mathrm{fmS}+; 8 \mathrm{st}]$.

${ }^{*}$ C. lindbergii (Mitt.) Hedenäs $-\mathrm{S}$; [Kaluzhskie Zase- 
ki Reserve; 47, 99 (Popova, 2002); 3, 4, 8, 17, 25, $39,42,60,65,70,71,72,76,87,92,94,95]$; on soil, soil-covered rocks and rotten wood on banks of rivers and lakes [13f; $1 \mathrm{~m} ; 1 \mathrm{fmS}+$; $8 \mathrm{st}]$.

* Campyliadelphus chrysophyllus (Brid.) R.S.Chopra - S; [8, 17, 24, 25, 46, 52, 65, 70, 71, 94, 97]; slopes to river valleys, overgrowing lime-pit; on limestones and calcareous soil [ $5 \mathrm{f} ; 3 \mathrm{~m} ; 5 \mathrm{fmS}+; 10 \mathrm{st}]$.

Campylidium calcareum (Crundw. \& Nyholm) Ochyra - R; [18, 24, 70, 76]; slopes to river valleys, overgrowing lime-pit; on limestones [1S+; 3st].

C. sommerfeltii (Myrin) Ochyra - R; [ 2 localities (Popova, 2001); 102]; slope to river valley, on rotten wood near spring [1st].

Campylium protensum (Brid.) Kindb. - R; [Baryatinsky Distr. (Popova, 2001); 3]; overgrowing lime-pit, edge of lake; on soil [2st].

C. stellatum (Hedw.) C.E.O.Jensen - R; [Baryatinsky Distr. (Popova, 2001); Kaluzhskie Zaseki Reserve (Popova, 2002); 24]; in bogging depression among overgrowed dumps in old lime-peat [1st].

Ceratodon purpureus (Hedw.) Brid. - C; [1, 2, 3, 4, $5,6,7,8,10,11,18,24,25,26,27,30,31,32,41$, $42,43,45,46,54,55,58,59,60,61,62,63,65$, $69,70,71,72,73,74,75,79,87,92,93,99,100$, $108]$; in various habitats and on different substrates, including disturbed and man-made [2f; $5 \mathrm{~m} ; 11 \mathrm{fmS}+$; 2st].

*Cirriphyllum piliferum (Hedw.) Grout - S; [Kaluzhskie Zaseki Reserve; 41, 47 (Popova, 2002); 89 (Peshkova, 1977); 6, 8, 17, 25, 39, 42, 48, 52, 61, 65, 87, $90,95,102,105]$; on dry sandy soil: dry meadows, roadsides, edges of pine forests; in rather moist habitats, mostly on bottoms of ravines in forests [8f; $3 \mathrm{~m}$; $3 \mathrm{fmS}+$; 2st].

* Climacium dendroides (Hedw.) F.Weber \& D.MohrC; $[1,2,6,9,19,21,23,29,32,33,41,42,44,49$, $50,60,72,73,87,90,92,94,98,99,100,103,105$, 110]; in forests in wet and shady habitats, e.g. edges of mesotrophic mires, old abandoned peat-mines among shrubs, in wet meadows; on soil, rotten wood, litter [8f; 8m; $11 \mathrm{fmS}+; 4 \mathrm{st}]$. Sporophytes were found in permanently wet places, usually edges of mires and old overgrowing peat-mines.

*Cratoneuron filicinum (Hedw.) Spruce - C; $[8,9,17$, $27,45,46,52,63,65,70,71,72,78,94,97]$; in humid habitats, mostly on soil and rocks near springs [6f; $1 \mathrm{~m} ; 15 \mathrm{st}]$.

Dichodontium pellucidum (Hedw.) Schimp. - S; [Zhukovsky Distr. (Ignatov, 1988 (MHA); 48, 52, 71, 72, 90, 94, 97]; banks of small rivers and creeks, on damp and wet rocks (limestones and sandstones) in more or less shady habitats [2f; $2 \mathrm{fmS}+; 5 \mathrm{st}]$.

Didymodon fallax (Hedw.) R.H.Zander - S; [7, 18, 24, $25,63,72,94,95]$; on soil-covered limestones, con- crete blocks, soil inclusive carbonates in open habitats [4f; $2 \mathrm{~m}$ (only on rocks); $2 \mathrm{fmS}+; 3 \mathrm{st}]$.

*D. rigidulus Hedw. $-\mathrm{S}$; [3, 8, 17, 18, 46, 52, 63, 72, $76,92,93,95,97,102]$; on limestone outcrop [9f; $2 \mathrm{~m} ; 3 \mathrm{fmS}+; 9 \mathrm{st}]$.

Dicranella cerviculata (Hedw.) Schimp. - R; [47 (V.I. Zolotov, unpublished data); Kaluzhskie Zaseki Reserve; 53 (Popova, 2002); 99]; on soil in forests and on rotten wood in boggy pine forest $[1 \mathrm{fmS}+]$.

D. crispa (Hedw.) Schimp. - R; 2 specimens from Kaluga Distr., Romodanovo, coll. E. Nikolsky, 30.VI.1911 (LE); (2S+).

D. heteromalla (Hedw.) Schimp. - C; [1, 6, 19, 20, 26, $28,31,33,41,42,48,49,50,51,55,56,61,62,70$, $71,77,80,87,90,99,101,106,108]$; coniferous forests, on bare sandy soil, under upturned roots, roadsides, overgrowing sides of trenches, rarely on rotten wood and rocks [ $6 \mathrm{fmS}+; 2 \mathrm{st}]$.

D. schreberiana (Hedw.) Hilf. ex H.A.Crum \& L.E.Anderson - R; [45, 72]; on bare soil, on soil on a wet roadside meadow [1f; $1 \mathrm{st}]$.

D. varia (Hedw.) Schimp. - R; [2 localities (Popova, 2001); 24, 45, 72, 94]; on bare soil in more or less open habitats [3fmS+; $1 \mathrm{st}]$.

Dicranodontium denudatum (Brid.) E.Britton - U; [90]; mixed coniferous and broad-leaved forest, on vertical side of damp sandstone [1st].

Dicranum bonjeanii De Not. - R; [47 (Popova, 2002); 65]; boggy pine forest, wet meadow; on soil [1st].

D. flagellare Hedw. - R; [33, 44, 48]; mixed coniferous and broad-leaved forest, on wet rotten wood in deep ravine [ $4 \mathrm{fmS}+; 1 \mathrm{st}]$.

D. fulvum Hook. - U; [48]; mixed coniferous and broadleaved forest, on dry bare sandstone [1st].

D. majus Turner - U; [19]; boggy birch forest, on litter [1f].

*D. montanum Hedw. - C; [88 (Peshkova, 1977); 1, 2, $4,5,6,8,9,10,18,19,23,26,27,29,30,31,33,39$, $40,42,43,44,46,47,48,49,51,54,56,58,60,61$, $62,70,71,73,77,80,87,90,92,94,99,101,103$, $106,108]$; on rotten wood, tree trunk bases, exserted tree roots in forests [2f; $17 \mathrm{fmS}+; 4 \mathrm{fmS}-;$ st].

D. polysetum Sw. - C; [88 (Peshkova, 1977); 1, 2, 6, 9, 19, 21, 26, 28, 29, 33, 35, 41, 42, 43, 47, 49, 50, 51, $80,87,90,99,101,104,106,108]$; pine forests, on soil [2fmS+; $2 \mathrm{st}]$.

*D. scoparium Hedw. - C; [88 (Peshkova, 1977); 1, 2, $3,4,6,8,9,10,11,18,19,20,21,26,27,28,29,31$, $32,33,39,41,42,43,47,48,49,51,55,58,61,62$, 77, 80, 87, 90, 93, 94, 97, 98, 99, 101, 108]; pine forests, on soil; on tree trunk bases, rotten wood in different forests, edges of mires [2m; $6 \mathrm{fmS}+; 17 \mathrm{st}]$. D. viride (Sull. \& Lesq.) Lindb. - S; [Kaluzhskie Zaseki Reserve; 47 (Popova, 2002); 39, 44, 48, 60, 62, 94, 97]; flood-plain and watershed broad-leaved forests, 
on trunks of broad-leaved trees, fresh rotten wood, occasionally on trunks of alder [11st].

* Drepanocladus aduncus (Hedw.) Warnst. - C; [3, 17, $18,19,21,23,39,45,63,65,70,72,95,97,100$, $103]$; in wet habitats, on soil, more rarely on rocks [6f; 6m; 9st].

D. polygamus (Bruch et al.) Hedenäs - R; [Mosalsky Distr. (Popova, 2001); 3, 23, 24]; boggy dumps and bottoms of abandoned lime-pits, in overgrowing peatmines, on soil [3S+; $5 \mathrm{~S}-]$.

Encalypta vulgaris Hedw. - U; [17, 52, 77]; on soilcovered limestone outcrops, on calcareous soil in birch forest [2S+; 2S-].

Eurhynchiastrum pulchellum (Hedw) Ignatov \& Huttunen - S; [47 (Popova, 2002); 88 (Peshkova, 1977); $5,8,17,18,25,33,42,46,49,58,60,72,76,77$, $94,95,107]$; on slumping slopes in forests, overgrowing meadows, on bare soil, more rarely on tree trunk bases and soil-covered outcrops [8fmS+; 14st].

*Eurhynchium angustirete (Broth.) T.J. Kop. - S; [Kaluzhskie Zaseki Reserve; 47 (Popova, 2002); 6, 33, 39, 42, 48, 49, 56, 58, 60, 61, 62, 70, 73, 94, 107, 109]; spruce and spruce-broad-leaved forest, mostly on slopes of ravines; on soil, litter and rotten wood [17f; $2 \mathrm{~m} ; 5 \mathrm{fmS}+; 5 \mathrm{st}]$.

Fissidens adianthoides Hedw. - U; [33]; swampy spruce forest, on base of birch trunk [ $1 \mathrm{fmS}+]$.

F. bryoides Hedw. - S; [88 (Peshkova, 1977); 10, 17, $18,44,46,48,62,69,70,71,72,87,91,94,102$, 109]; on wet bare soil in forests, on banks of creeks [9S+; 4S-].

F. exiguus Sull. - U; [Zhukovsky Distr. (Ignatov, 1988 (MHA)]; on limestone in open habitat [1S-].

F. exilis Hedw. - S; [88 (Peshkova, 1977); 1, 4, 17, 40, $49,58,87]$; on wet bare soil in forests [3S+].

F. gracilifolius Brugg.-Nann. \& Nyholm - S; [18, 46, $48,52,70,72,73,76,91,92,94,95,97,102]$; floodplane broad-leaved forest, on wet small limestone rocks, occasionally on wet pieces of brick in ravine [17fmS+].

F. taxifolius Hedw. - C; [89 (Peshkova, 1977); 5, 8, $10,17,18,19,23,27,30,32,40,44,46,54,55,56$, $48,52,63,69,70,72,91,92,94,95,97,98,102$, $105]$; on slumping slopes and wet bare soil in forests, swampy alder forests on banks of creeks, more rarely on wet limestone [11S+ (both on rocks and soil), 32S-].

Fontinalis antipyretica Hedw. - S; [2 localities (Popova, 2001); 4, 8, 52, 63, 90, 96]; springs, cold clear creeks and small rivers with sandy or stony bottom [5st].

Funaria hygrometrica Hedw. - C; [2, 4, 6, 8, 10, 17, $27,32,42,45,49,55,56,59,65,70,71,72,73,74$, $78,79,87,92,93,94,95,97,100,101,108]$; on wet bare soil in more or less open habitats, often on fireplaces $[7 \mathrm{~S}+]$.
Grimmia muehlenbeckii Schimp. - U; [Yuhnovsky Distr., left bank of Vorya River near Alexandrovka]; on granite boulder $[1 \mathrm{~m}]$.

G. pulvinata (Hedw.) Sm. - U; [24]; dumps of abandoned lime-pits, on limestone [1S+].

Gymnostomum calcareum Nees \& Hornsch. - U; [52]; in moist limestone cave [2st].

Gyroweisia tenuis (Hedw.) Schimp. - R; [17, 65]; niches of large limestone rocks among meadows at a river bank [2f; 1st].

Hamatocaulis vernicosus (Mitt.) Hedenäs - R; [2 localities (Rabotnov, 1929); Kaluzhskie Zaseki Reserve (Popova, 2002)]; wet and less stable places on Sphagnum mires.

Hedwigia ciliata (Hedw.) P. Beauv. - U; [47 (Zhadovsky, 1928; Popova, 2002); 47]; on soil-covered sandstone outcrop $[2 \mathrm{~S}+]$.

Helodium blandowii (F.Weber \& D.Mohr) Warnst. R; [Spas-Demensky Distr. (Rabotnov, 1929); Kaluzhskie Zaseki Reserve; 47, 53, 99 (Popova, 2002); 9 (Peshkova, 1965 (MW); 9]; eutrophic mires, drained overgrowing mire with hypnalean mosses, boggy pine forests; on soil [3S+].

Herzogiella seligeri (Brid.) Z.Iwats. - S; [Kaluzhskie Zaseki Reserve (Popova, 2002);42, 44, 48, 49, 56, $70,103,107,108]$; rotten wood in forests [12S+].

Homalia trichomanoides (Hedw.) Bruch et al. - S; [Kaluzhskie Zaseki Reserve (Popova, 2002); 47 (Zhadovsky, 1928; Popova, 2002); 18, 40, 33, 39, $44,48,52,56,58,60,62,66,69,70,73,94,95,97$, $99,102,107,108]$; broad-leaved, coniferous-broadleaved and spruce-aspen forests; on trunks of broadleaved trees and aspen, more rarely on soil-covered outcrops $[12 \mathrm{~S}+$ (only on tree trunks and tree trunk bases); 14S-].

Homomallium incurvatum (Schrad. ex Brid.) LoeskeS; [47 (Zhadovsky, 1928); 18, 52, 70, 72, 76, 91, 92, $94,95,102]$; on limestones, more rarely on sandstones [14S+].

Hygroamblystegium fluviatile (Hedw.) Loeske - U; [18]; river bank, on rock not high above water level [1S-].

H. humile (P.Beauv.) Vanderp., Goffinet \& Hedenäs $\mathrm{S} ;[23,31,46,51,65,99,105]$; temporarily flooded habitats, on soil, bases of sedge tussocks, among Typha, etc. [4S+; 5S-].

H. tenax (Hedw.) Jenn. - R; [48, 52, 65, 97]; on wet limestones in creeks [3S+; 3S-]. Sporophytes were found for the first time in the middle part of European Russia.

H. varium (Hedw.) Mönk - S; [88 (Peshkova, 1977); $18,33,47,48,49,55,62,70,71,77,95,97]$; on soil, tree trunk bases, rocks, rotten wood [6S+ (on rocks and tree trunk bases); 5S-].

Hygrohypnum luridum (Hedw.) Jenn. - R; [17, 70, 72, 
$76,94]$; on limesones and concrete blocks in temporarily flooded places on river banks [5S+; $2 \mathrm{~S}-]$.

Hylocomium splendens (Hedw.) Bruch et al. - S; [Kaluzhskie Zaseki Reserve, 47 (Popova, 2002); 1, $6,26,29,42,49,58,87,90,99,101,106]$; mossy coniferous and coniferous-broad-leaved forests, on soil and rotten wood [4f; $3 \mathrm{~m} ; 1 \mathrm{fmS}+]$.

Hymenostylium recurvirostrum (Hedw.) Dixon. - U; [46]; slope to river valley, in wet niche of limestone [1st].

*Hypnum cupressiforme Hedw. - S; [18, 33, 40, 42, $45,46,47,48,49,52,58,60,62,65,70,71,72,73$, $74,92,94,95,97,99]$; broad-leaved and birch forests, on tree trunk bases, more rarely on soil and soilcovered outcrops [33f; $8 \mathrm{~m}$ (on soil and tree trunk bases); $5 \mathrm{fmS}+$; 4st].

Isothecium alopecuroides (Lam. ex Dubois) Isov. - U; [48]; spruce-broad-leaved forest, on the base of an oak trunk [1st].

Leptobryum pyriforme (Hedw.) Wilson - S; [88 (Peshkova, 1977); 17, 31, 40, 46, 50, 52, 71, 72, 76, 90, $92,100,106]$; on bare soil, under upturned roots of fallen trees, rotten wood, soil-covered outcrops [6S+ (on all types of substrates); 6S-].

Leptodictyum riparium (Hedw.) Warnst. - C; $[8,17$, $23,40,42,44,46,63,72,77,100]$; in humid habitats, mostly on sunken wood in rivers, springs and lakes [3S+ (in temporarily dried habitats); 6S-].

Leskea polycarpa Hedw. - C; [5, 17, 23, 25, 33, 40, $42,60,61,63,72,77,91,92,95,97,99]$; floodplane forests, banks of lakes and rivers; on tree trunks, mostly on trunks of Salix, rarely on rocks [23S + (both on rocks and tree trunks); 1S-].

Leucobryum glaucum (Hedw.) Ångstr. - U; [33 (collection of Peshkova, 1962, MW)]; mossy pine forest, on soil.

*Leucodon sciuroides (Hedw.) Schwägr. - S; [Kaluzhskie Zaseki Reserve, 47 (Popova, 2002); 17, 33, 39, 42, $44,48,52,58,60,62,92]$; on trunks of old broad-leaved trees, rarely on limestones and sandstones [1f; 19st].

*Mnium lycopodioides Schwägr. - S; [47 (V.I. Zolotov, unpublished data); 10, 17, 18, 62, 69, 71, 72, $76,92,97,102,107]$; ravines in forests, on soil and on soil-covered outcrops [13f; 3m; 4st].

M. marginatum (Dicks.) P.Beauv. - R; [Kaluga Distr. (Popova, 2001); 47 (Popova, 2002); 92, 95]; upland broad-leaved forests, on soil, rarely on soil-covered sandstone outcrops [2S-].

*M. stellare Hedw. - C; [5, 6, 18, 27, 30, 33, 42, 44, $46,48,49,50,52,58,62,70,71,72,73,76,77,87$, $90,92,94,95,96,97,102,103,107]$; on bare soil in forests, soil-covered shady outcrops [29f; $7 \mathrm{~m} ; 1 \mathrm{fmS}$; $4 \mathrm{fmS}+$; 4st].

Myrinia pulvinata (Wahlenb.) Schimp. - R; [33, 40]; flood-plain broad-leaved forests, on tree trunks [2S+].
Neckera pennata Hedw. - R; [Kaluzhskie Zaseki Reserve, 47 (Popova, 2002); 9, 28, 30, 31, 33, 39, 44, 47, 48, 49, 56, 58, 60, 90, 107]; broad-leaved, coniferous-broad-leaved and spruce-aspen forests, on trunks of broad-leaved trees and aspens [18S+; 6S-].

N. complanata (Hedw.) Huebener - U; [47 (Zhadovsky, 1928)]; on sandstones. No herbarium specimens were found, thus the record is somewhat doubtful. This species is very rare in the middle part of European Russia, the closest locality being in NW of Tver Province (ca. $400 \mathrm{~km}$ from this place), where it grows on limestone. From the other side, the Chertovo Gorodishche is the only locality of Pohlia elongata in the whole Middle European Russia and many other rare species occur there.

Niphotrichum canescens (Hedw.) Bednarek-Ochyra \& Ochyra-U; [90]; bottom of abandoned pit, on sandy soil [1f].

Orthotrichum anomalum Hedw. - R; [17, 52]; slopes to river valleys, on dry exposed limestones [3S+].

*O. obtusifolium Brid. - S; [4, 18, 25, 29, 31, 42, 44, $46,49,51,55,63,74,87,92,94,102,103]$; on tree trunks, mostly on poplars [2f; $5 \mathrm{fmS}+; 5 \mathrm{st}]$.

O. pallens Bruch ex Brid. - R; [44, 46, 62, 94]; broadleaved forestü, on tree trunks, mostly on inclined trunks $[4 \mathrm{~S}+]$.

O. pumilum Sw. ex anon. - S; [8, 18, 25, 31, 42, 44, $61,65,73,77,91,92,107]$; on tree trunks [8S+].

O. spesiosum Nees - C; $[1,3,4,5,6,8,10,11,17,18$, $19,23,25,27,30,31,32,33,39,40,41,42,43,44$, $46,49,55,58,61,62,65,66,71,73,77,87,103$, $105]$; on tree trunks [14S+].

* Oxyrrhynhium hians (Hedw.) Loeske - C; [8, 17, 18, $31,33,48,52,63,70,71,72,76,77,79,91,92,94$, 95, 97, 102, 103]; forests, overgrowing meadows; on slumping slopes, bare soil, more rarely on rocks [14f; $1 \mathrm{~m} ; 11 \mathrm{fmS}+; 20 \mathrm{st}]$.

Palustriella decipiens (De Not.) Ochyra - U; [96]; broad-leaved forest on slope to river valley, on soil along a stream in ravine bottom [1f].

Paraleucobryum longifolium (Hedw.) Loeske - U; [47 (Zhadovsky, 1928; Popova, 2002)]; on sandstone outcrops.

Pleuridium subulatum (Hedw.) Rabenh. - S; [4, 6, 8, $74,78,87,90,94]$; on bare soil in more or less open habitats, mostly on molehills at forest edges and overgrowing meadows $[6 \mathrm{~S}+]$.

Philonotis caespitosa Jur. - U; [47, 53 (Popova, 2002)]; boggy pine forest, on soil.

P. fontana (Hedw.) Brid. - R; [Dzerzhinsky Distr.; 100]; wet meadow and mesotrophic mires; on soil $[1 \mathrm{~m}$, 2st].

Physcomitrium pyriforme (Hedw.) Hampe - S; [11, 17, $32,55,74,78,94,95]$; roadsides, edges of arable fields, abandoned field; on wet bare soil [5S+]. 
Plagiomnium affine (Blandow ex Funck) T.J.Kop. - S; $[1,6,19,31,33,39,42,49,56,60,61,77,87,90$, $103,106]$; spruce and mixed forests, on litter [13f; $6 \mathrm{~m} ; 5 \mathrm{st}]$.

P. cuspidatum (Hedw.) T.J. Kop. - C; [1, 4, 5, 6, 8, 17 , $18,19,24,25,28,29,31,33,42,44,47,48,49,56$, $58,60,61,69,70,72,76,77,87,90,92,93,94,96$, $101,102,103,105,106,107,108]$; in more or less humid shady habitats; on soil, rotten wood, tree trunk bases, soil-covered outcrops [25S+ (on all types of substrates); 3S-].

P. elatum (Bruch et al.) T.J.Kop. - S; [Kaluzhskie Zaseki Reserve, 6 (Popova, 2002); 19, 27, 31, 46, 48, 58, 106]; alder swamps, bushy wet meadows, old and overgrowing peat mines; on soil [3f; $3 \mathrm{~m} ; 1 \mathrm{fmS}+$; $1 \mathrm{st}]$.

P. ellipticum (Brid.) T.J. Kop. - C; [17, 19, 31, 32, 33, $39,61,63,87,42,43,47,79,97,103,105,108]$; in humid habitats, mostly on banks of creeks, on soil [6f; 4m; $1 \mathrm{fmS}+; 7 \mathrm{st}]$.

P. medium (Bruch et al.) T.J.Kop. - S; [Kozelsky Distr. (Popova, 2002); 25, 33, 42, 44, 48, 58, 70, 87, 90, 99, 106, 107]; mixed forests, on soil and litter [11S+; 2S-].

P. rostratum (Schrad.) T.J. Kop. - S; [Kaluzhskie Zaseki Reserve (Popova, 2002); 18, 19, 46, 52, 72, 76, 92, 96, 97, 102, 106]; broad-leaved forests, often on bottoms of ravines; on soil-covered limestone outcrops and on calcareous soil [11S+; 5S-].

*P. undulatum (Hedw.) T.J. Kop. - C; [6, 8, 17, 18, 27 , 47, 48, 49, 52, 58, 62, 69, 65, 79, 87, 90, 92, 94, 95, $97,98,102,105,107]$; on soil in humid and shady habitats, mostly in alder swamps, on banks of lakes and creeks, slopes of ravines in forests [17f; $5 \mathrm{~m}$; $3 \mathrm{fmS}+$ ]. Sporophytes were found for the first time in the middle part of European Russia and probably in the whole Russia.

*Plagiothecium cavifolium (Brid.) Z.Iwats. - C; [Kaluzhskie Zaseki Reserve, 47 (Popova, 2002); 27, 31, 33, 46, 48, 49, 52, 60, 62, 71, 77, 90, 94, 95, 107]; on bare soil in forests, mostly on slopes of ravines, rarely on tree trunk bases, soil-covered sandstone outcrops [2f; 1m; 13fmS+; 19st].

P. curvifolium Schlieph. ex Limpr. - R; [Kaluzhskie Zaseki Reserve (Popova, 2002); 6]; spruce forests, on rotten wood and on spruce trunk bases $[2 \mathrm{~S}+]$. The species is likely more widespread, but a revision of material is needed.

P. denticulatum (Hedw.) Bruch et al. - C; [1, 4, 6, 17, 23, 27, 31, 42, 44, 50, 55, 56, 58, 47, 49, 70, 72, 73, 77, 79, $87,90,98,99,102,106,108]$; on soil, rotten wood, soil-covered sandstone outcrops in forests [4S+; 5S-].

P. denticulatum var. undulatum R.Ruthe ex Geh. - R; [Kozelsky Distr. (Popova, 2000); Kaluzhskie Zaseki Reserve (Popova, 2002)]; edges of boggy dishes in pine forests.
P. laetum Bruch et al. - C; $[1,4,6,8,10,19,28,29$, $30,31,32,33,39,42,44,46,49,54,56,60,71,73$, 77, 90, 92, 93, 97, 99, 103, 107, 108, 109]; on tree trunk bases, rotten wood in forests [13S+; 3S-].

P. latebricola Bruch et al. - U; [47 (Popova, 2002); 47]; on trunk of old oak, rotten wood, soil-covered outcrop of sandstone [2fmS+; $1 \mathrm{st}]$.

P. nemorale (Mitt.) A.Jaeger - R; [47 (Popova, 2002); $27]$; in a mixed forest on soil-covered sandstone outcrop, in alder swamp on the tree trunk base [1f].

* Platygyrium repens (Brid.) Bruch et al. - C; [1, 4, $5,6,8,17,18,25,27,32,39,40,42,44,46,48$, $52,55,56,58,60,70,71,72,76,92,93,94,97$, 107]; broad-leaved and coniferous-broad-leaved forests, on tree trunks, fresh rotten wood [4f; 5m; $10 \mathrm{fmS}+]$.

Pleurozium schreberi (Brid.) Mitt. - C; [1, 2, 4, 6, 19, $20,21,25,26,28,29,35,41,42,43,47,49,51,58$, $61,77,80,87,90,98,101,104,106,108]$; on soil in mossy pine forests; on tree trunk bases, rotten wood in other types of forests [3f; $2 \mathrm{~m} ; 2 \mathrm{fmS}+; 4 \mathrm{st}$ ].

Pogonatum urnigerum (Hedw.) P.Beauv. - R; 4 specimens collected near Kaluga by E. Nikolsky: 17.IV.1911; 17.IV.1911; 30.VI.1911; 2.IX.1911 (all in LE) [3fmS+; $1 \mathrm{fmS}-]$.

Pohlia andalusica (Höhn.) Broth. - U; [Maloyaroslavetsky Distr. (MW)]; depression of watershed area, in wet meadow.

P. cruda (Hedw.) Lindb. - U; [47 (Popova, 2002); 47]; on soil-covered sandstone outcrop [1 fmS+].

P. elongata Hedw. - U; [47 (Zhadovsky, 1928; Popova, 2002)]; on soil-covered sandstone outcrop [1S+].

P. nutans (Hedw.) Lindb. - C; [1, 6, 17, 20, 21, 33, 42, 49, 50, 56, 69, 70,87, 90, 92, 106]; forests, oligotrophic mires; on tree trunk bases, rotten wood, bare soil, soil-covered outcrops [8S+; 1S-].

P. melanodon (Brid.) A.J.Shaw - U; [94]; on wet bare soil on a creek bank [1fmS+;1st].

P. wahlenbergii (F.Weber \& D.Mohr) A.L.Andrews S; [Kaluzhskie Zaseki Reserve, 47 (Popova, 2002); $8,17,18,31,45,58,63,93]$; on wet bare soil and sandstone outcrops at creek banks [3m;6st].

Polytrichastrum formosum (Hedw.) G.L.Sm. - S; [1, $6,19,42,49,58,60,87]$; spruce and spruce-broadleaved forests, on soil, rotten wood, under upturned roots of fallen trunks [ $5 \mathrm{fmS}+; 1 \mathrm{st}]$.

P. longisetum (Sw. ex Brid.) G.L.Sm. - R; [Kaluzhskie Zaseki Reserve, 47 (Popova, 2002); 88 (Peshkova, 1977); 33, 49, 50]; similar to previous and also on the bank of overgrowing peat mines [1f; $3 \mathrm{fmS}+]$.

P. pallidisetum (Funck) G.L.Sm. - U; [39]; in dish in broad-leaved forest on wet rotten wood [ $1 \mathrm{fmS}+]$.

Polytrichum commune Hedw. - C; [1, 2, 6, 9, 19, 20, $21,22,26,28,29,32,33,35,41,44,47,49,50,51$, $56,60,77,80,87,90,99,101,104,106,108$.]; edg- 
es of mires, boggy forests, Sphagnum mires; on soil, rarely on rotten wood [3f; $3 \mathrm{~m} ; 7 \mathrm{fmS}+; 1 \mathrm{st}]$.

P. juniperinum Hedw. - C; [88 (Peshkova, 1977); 1, 2, $4,5,6,8,10,11,17,25,26,31,32,41,42,43,49$, $50,54,55,70,71,75,79,87,90,93,94,97,99$, 101, 108]; pine forests, roadsides in forests, forest margins, forest clear-cuttings; on dry sandy soil [2f; $2 \mathrm{~m} ; 5 \mathrm{fmS}+; 2 \mathrm{st}]$.

P. piliferum Hedw. - S; [88 (Peshkova, 1977); 1, 2, 4, $6,26,32,40,41,43,60,70,71,75,90,99]$; on dry sandy soil in open habitats $[5 \mathrm{fmS}+]$.

P. strictum Brid. - S; [Kaluzhskie Zaseki Reserve, 47, 53 (Popova, 2002); 20, 21, 22, 29, 35, 77, 80, 104, 109]; sphagnous mires, on mossy hummocks [4fmS+].

P. swartzii Hartm. - R; [Spas-Demensky Distr., Yuhnovsky Distr. (Popova, 2001, cited by Peshkova).

Pseudobryum cinclidioides (Huebener) T.J.Kop. - R; [Kozelsky Distr. (Popova, 2002); 47, 90]; swampy banks of brooks in forests, on wet peaty soil [2f].

* Pseudoleskeela nervosa (Brid.) Nyholm - C; [5, 17, $18,27,33,44,46,52,58,70,73,76,77,91,92,93$, $94,95,97,102,107]$; on trunks of broad-leaved trees and Betula, rarely on soil-covered outcrops and fresh rotten wood [28f; $6 \mathrm{fmS}+; 11 \mathrm{st}$ ].

Pterigynandrum filiforme Hedw. - R; 57 (Popova, 2001); 60]; broad-leaved forests, on trunks of old trees [1f].

Ptilium crista-castrensis (Hedw.) De Not. - S; [Kaluzhskie Zaseki Reserve, 47 (Popova, 2002); 1, $2,6,19,42,49,51,61,90,99,106]$; on soil in mossy coniferous forests, rarely on tree trunk bases and rotten wood in mixed forests [3f; $2 \mathrm{~m} ; 4 \mathrm{st}]$.

Pylaisia polyantha (Hedw.) Bruch et al. - C; [1, 4, 5, $8,10,17,18,25,27,30,31,32,39,42,44,46,49$, $52,55,56,58,61,62,63,66,71,73,97,90,91,92$, $97,102,103]$; on tree trunks, rarely on soil-covered outcrops $[12 \mathrm{~S}+]$.

*Rhizomnium punctatum (Hedw.) T.J. Kop. - C; [47 (Popova, 2002); 1, 6, 9, 11, 17, 18, 19, 23, 27, 33, $39,42,44,48,49,50,56,58,62,70,87,90,94,97$, $98,99,101,102,103,105,108]$; on wet strongly decayed wood, on soil-covered outcrops, on wet soil in forests [ $8 \mathrm{f} ; 9 \mathrm{~m} ; 11 \mathrm{fmS}+; 4 \mathrm{st}]$.

Rhodobryum roseum (Hedw.) Limpr. - S; 447 (Popova, 2002); 1, 6, 19, 21, 28, 29, 30, 33, 42, 49, 58, 60, 87, 90, 98, 106]; spruce forests, on litter [1m; 5st].

Rhynchostegium arcticum (I.Hagen) Ignatov \& Huttunen - R; [72, 94, 95]; a broad-leaved forest on slopes to river valleys; on wet small limestone rocks, rarely on fresh rotten wood and exserted roots of Alnus near limestone outcrops [4S+].

R. riparioides (Hedw.) Cardot - U; [63]; a slope to the river valley, in running water of a spring [1S-].

Rhytidiadelphus squarrosus (Hedw.) Warnst. - C;
[Kaluzhskie Zaseki Reserve, 47 (Popova, 2002); 1, $2,8,10,18,19,26,27,32,39,41,42,49,55,61$, $66,87,90,91,94,99,101,108]$; flood-plains of small rivers, wet meadows, grassy forest margins, abandoned forest clear-cuttings and roads; on soil [7f; 2m; 6st].

R. subpinnatus (Lindb.) T.J.Kop. - R; [48 (MW)]; broad-leaved forest in ravine bottom.

*R. triquetrus (Hedw.) Warnst. - C; 899 (Peshkova, 1977); 8, 18, 33, 42, 48, 52, 56, 58, 70, 72, 73, 80, 87, 90, 92, 94, 98, 99, 106, 107, 108]; coniferous, mixed and Betula forests, on litter [16f; $4 \mathrm{~m} ; 3 \mathrm{fmS}+$; $3 \mathrm{st}]$.

Sanionia uncinata (Hedw.) Loeske - C; $[1,2,4,6,8$, $10,11,18,19,25,27,31,32,39,40,41,42,47,49$, $55,56,61,72,73,77,92,103,105,106]$; on tree trunks at bases as well as high above ground, rotten wood, rarely on litter in forests [9S+ (on all substrates); 2S-].

Schistidium apocarpum (Hedw.) Bruch et al. - R; [Ulyanovsky Distr. (Popova, 2001); 63]; on siliceous limestones [1S+].

S. crassipilum H.H.Blom - R; [72, 92]; broad-leaved forests on slopes to river valley; on dry sunny limestones $[2 \mathrm{~S}+]$.

S. dupretii (Thér.) W.A.Weber - R; [8, 25, 63, 94, 95]; on limestones, concrete blocks [7S+].

S. submuticum Broth. ex H.H.Blom - S; [42, 92, 93, 94, 99]; on limestones, concrete blocks [6S+].

Schistostega pennata (Hedw.) F.Weber \& D.Mohr R; [47 (Zhadovsky, 1928; Popova, 2002); 33, 90]; in moist caves of sandstone and on upturned roots of fallen trees in swampy spruce forest $[4 \mathrm{fmS}+]$.

Sciuro-hypnum curtum (Lindb.) Ignatov - C; $[1,6$, $19,29,30,31,33,39,42,49,50,51,56,60,62$, $77,87,90,105,106,108]$; spruce and mixed forests; on litter, rarely on tree trunk bases and rotten wood [11S+; 1S-].

S. populeum (Hedw.) Ignatov \& Huttunen - S; [47 (Popova, 2002); 17, 18, 25, 27, 46, 48, 52, 58, 63, 70, 72, 73, 92, 94, 95, 97, 107, 102]; broad-leaved forests; on soil-covered outcrops of limestone, rarely on broad-leaved tree trunk bases, sandstones, granites [27S+; 6S-].

S. reflexum (Starke) Ignatov \& Huttunen - C; [47 (Popova, 2002); 5, 27, 30, 39, 41, 44, 46, 48, 58, 66, 72, 73, 76, 95, 105, 107, 108]; broad-leaved forest, floodplain Alnus and Salix forests; on tree trunk bases and rotten wood $[15 \mathrm{~S}+]$.

Scorpidium cossonii (Schimp.) Hedenäs - U; [80 (Peshkova \& Abramova, 1965 (MW)]; oligotrophic mire, in hollows.

Seligeria calcarea (Hedw.) Bruch et al. - U; [94]; abandoned lime-pits, on limestones; shady limestone rocks near creek $[3 \mathrm{~S}+]$. 
S. campylopoda Kindb. - R; [17, 91, 94]; on wet shady limestones [10S+; 2S-].

S. pusilla (Hedw.) Bruch et al. - R; [18, 52, 72, 76, 92, 95]; on wet shady limestones [7S+; 3S-].

Serpoleskea subtilis (Hedw.) Loeske - C; [17, 24, 27, $30,39,46,60,70,72,73,76,92,95]$; on tree trunk bases, rotten wood, boulders [15S+; 2S-].

Sphagnum angustifolium (C.E.O.Jensen ex Russow) C.E.O.Jensen - C; [Ukchnovsky Distr. (Gerasimov, 1924); 12, 16, 57, 67, 68, 80, 81, 82, 83, 84, 85, 86 and 9 other localities (Peshkova, 1975); 47, 99 (Popova, 2002); 21, 22, 35, 77, 99, 104, 109, 110]; oligo-, mesooligo- and mesotrophic mires; on moss hummocks; one of the most common Sphagnum in bogs of the province [28S-].

S. balticum (Russow) C.E.O.Jensen - S; [14, 57, 64, $68,80,81,82,85$ and 4 other localities (Peshkova, 1975)]; oligo- and mesotrophic bogs; on bases of hummocks and in hollows [24S-].

S. capillifolium (Ehrh.) Hedw. - S; [33, 80, 82, 83, 84, 85 and 4 other localities (Peshkova, 1975); 99 (Popova, 2002); 21]; all types of oligotrophic bogs, on tops and sides of Sphagnum hummocks, rarely in hollows and in boggy forests; once in mesotrophic sedge-sphagnous mire [16S-].

S. centrale C.E.O.Jensen - C; [Kaluzhskie Zaseki Reserve; 47, 99 (Popova, 2002); 12, 13, 14, 34, 36, 37, $38,64,67,68,81,85$ and 5 other localities (Peshkova, 1975); 1, 9, 20, 21, 29, 35, 49, 50, 51, 77, 99, 104, 110]; edges of bogs and boggy forests [17S-].

S. compactum Lam. \& DC. - R; [33 (Peshkova, 1975); 53 (Majorov, 2001)]; pine forest with Molinia; wet and overgrowing road along clear-cutting area of 34 years old $[3 \mathrm{~S}+]$.

S. contortum Schultz - R; [Iznoskovsky Distr. (Gerasimov, 1924); 13, 14 (Peshkova, 1975)]; eutrophic mires, birch forests, in grass associations [8S-].

S. cuspidatum Ehrh. ex Hoffm. - R; [80, 82, 85 and 2 other localities (Peshkova, 1975); 104]; in hollows in oligotrophic bogs [16S-].

S. fallax (H.Klinggr.) H.Klinggr. - C; [Kaluzhskie Zaseki Reserve; 47 (Popova, 2002); 12, 13, 37, 64, 67, $68,80,81,82,83,84,85,86$ and 9 other localities (Peshkova, 1975); 20, 21, 22, 28, 29, 35, 51, 77, $104,109,110]$; one of the most common and abundant Sphagnum in all types of bogs; growing on sides of hummocks and in hollows [54S-, 1S+].

S. fimbriatum Wilson - S; [Khvastovichsky Distr., 47 (Popova, 2002); 12, 13 and 2 other localities (Peshkova, 1975); 50,110]; mesotrophic and eutrophic mires, Phragmites, Carex + Sphagnum, Eriophorum + Betula, Salix + Betula, and Betula + Populus tremula communities; also in bogging peat pits [9S-, 2S+].

S. flexuosum Dozy \& Molk. - S; [Kaluzhskie Zaseki Reserve, 47, 99 (Popova, 2002); 12, 28, 64, 80, 81,
$82,83,84,85,86$ and 5 other localities (Peshkova, 1975); 110]; edges of oligo- and mesotrophic bogs [36S-, 2S+].

S. fuscum ((Schimp.) H.Klinggr. - S; [80 (Rabotnov; 1929); 13, 21, 34, 57, 67, 80, 81, 82, 83, 84, 85 and 2 other localities (Peshkova, 1975)]; on mesotrophic sedge-sphagnous mire; oligotrophic bogs in northwest parts of the province, mostly on tops and slopes of hummocks, more rarely in marginal parts of hollows, and, according to literature, also in eutrophic mires [29S-].

S. girgensohnii Russow - C; [Kaluzhskie Zaseki Reserve, 47 (Popova, 2002); 12, 13, 14, 15, 26, 57, 67, 80 and 10 other localities (Peshkova, 1975); 1, 2, 9, $19,20,21,22,28,29,32,35,39,49,50,80,99$, 104]; eutrophic mires, edges of mires, swampy and wet mossy forests [38S-].

S. inundatum Russow - U; [36 (Peshkova, 1975)] [1S-]. S. jensenii H. Lindb. - U; [80 (Peshkova, 1975)]; Eriophorum vaginatum + Sphagnum pine forests, in wet hollows [3S-].

S. magellanicum Brid. - C; [Iznoskovsky Distr. (Gerasimov, 1924); 12, 13, 28, 57, 67, 68, 80, 81, 82, 85, 86 and 6 other localities (Peshkova, 1975); 21, 22, 28, $35,77,80,99,104,109]$; oligo- and mesooligotrophic bogs, on tops of hummocks with $S$. angustifolium, more rarely on hummock sides and in hollows. One of the most common mosses of oligotrophic bogs [42S-].

S. majus (Russow) C.E.O.Jensen - R; [80, 82 (Peshkova, 1975)]; central part of Ignatovo Bog, in hollows and otherwise wet places, and in Sphagnum+Eriophorum communities [10S-].

S. obtusum Warnst. - R; [Khvastovichsky Distr. (Popova, 2001); 53]; mesotrophic sedge-sphagnous bog.

S. palustre L. - S; [12, 13, 16, 28, 34, 36, 81, 99 and 5 other localities (Peshkova, 1975)]; boggy forests, eutrophic mires, drained and grassy habitats, edges of oligotrophic bogs [15S-].

S. papillosum Lindb. - U; [80 (Peshkova, 1975)]; in hollows in Ignatovo Bog [8S-].

S. platyphullum (Lindb. ex Braithw.) Warnst. - R; [3 localities (Peshkova, 1975)] [4S-].

S. riparium Ångstr. - S; [Khvastovichsky Distr., 47 (Popova, 2002); 15, 64 (Peshkova, 1975); 9, 21, 22, 29, 110]; mesoeutrophic mires, at edges of hollow and peat pits, in bogging depressions [3S-].

S. rubellum Wilson - R; [80, 82, 83, 84 (Peshkova, 1975)]; mostly among other Sphagna in forested Eriophorum vaginatum + Sphagnum patrs of oligotrophic bogs [10S-].

S. russowii Warnst. - R; [13, 14, 34, 67 and 2 other localities (Peshkova, 1975); 35]; eutrophic and mesotrophic mires, birch and birch-pine stands; in herb communities at edges of mires; also found on moss 
hummock in mesooligotrophic bog [13S-].

S. squarrosum Crome - C; [Kaluzhskie Zaseki Reserve, 47, 99 (Popova, 2002); 12, 13, 14, 28, 34, 36, 37, 57, 67, 81, 82, 83 and 2 other localities (Peshkova, 1975); 1, 2, 6, 9, 19, 20, 29, 32, 35, 49, 50, 51, 104, 110]; eutrophic mires, edges of mires and overgrowing peat pits, boggy forests, banks of streams in forest [25S- $5 \mathrm{~S}+]$.

S. subsecundum Nees - S; [Kaluzhskie Zaseki Reserve (Popova, 2002); 83, 84, 86 and 5 other localities (Peshkova, 1975)]; boggy forests and meadows, eutrophic mires, edges of meso- and oligotrophic bogs [16S-].

S. tenellum (Brid.) Pers. ex Brid. - U; [80 (Peshkova, 1975)]; central part of Ignatovo Bog in Eriophorum vaginatum + Ericaceae + Sphagnum, Pinus + Eriophorum vaginatum and in Betula alba communities [11S-].

S. teres (Schimp.) Ångstr. - R; [Iznoskovsky Distr. (Gerasimov, 1924); Kaluzhskie Zaseki Reserve, 90 (Popova, 2002); 14 (Peshkova, 1975)]; boggy spruce, birch and alder forests, bogging meadows and lakes, unstable parts of mires [3S-].

S. warnstorfii Russow - R; [13, 14, 67 and 2 other localities (Peshkova, 1975)]; eutrophic, rarely mesotrophic mires, in communities of Betula, Salix and Carex [11S-].

Stereodon pallescens (Hedw.) Mitt. - C; [4, 6, 18, 42, 44, 46, 47, 58, 70, 72, 77, 92, 95, 97, 99, 103, 106, $108]$; on tree trunks, rarely on soil-covered outcrops [21S+ (on all types of substrates); 1S-].

Straminergon stramineum (Dicks. ex Brid.) Hedenäs $\mathrm{R}$; [21, 45, 109]; in wet and unstable parts of bogs, and at base of slope to river valley, on soil near spring [2st]. *Syntrichia ruralis (Hedw.) F.Weber \& D.Mohr - S; [1, $2,6,17,25,26,33,41,42,43,52,60,61,63,65,73$, $75,90,92,93,99,100]$; in dry and exposed habitats: edges of pine forests, xeric meadows, slopes with limestone outcrops, concrete blocks [6f; $1 \mathrm{fmS}+$; 9st].

Taxiphyllum wissgrillii (Garov.) Wijk \& Margad. - R; [47 (Popova, 2002); 18, 46, 48, 52, 73, 97]; in broadleaved forests on slopes to river valleys, on wet shady limestones and sandstones [1f; $2 \mathrm{fmS}+; 7 \mathrm{st}$ ]. Sporophytes were found for the first time in the middle part of the European Russia.

Tetraphis pellucida Hedw. - S; [Kaluzhskie Zaseki Reserve, 47 (Popova, 2002); 19, 33, 35, 42, 44, 48, $49,50,60,87,90,99,108]$; spruce and mixed forests, on wet strongly decayed wood, on vertical surface of sandstone in forest [ $6 \mathrm{~S}+($ both on rocks and rotten wood); 5S-].

*Thuidium assimile (Mitt.) A.Jaeger - S; [88 (Peshkova, 1977); Kaluzhskie Zaseki Reserve, 47 (Popova, 2002); 3, 8, 17, 25, 42, 52, 61, 63, 69, 70, 76, 87, 90, $92,93,94,96,101]$; on soil on meadows, forest egdes, abandoned forest road; in rather open pine and birch forests, rarely on tree trunk bases and limestones in broad-leaved forests [11f; $20 \mathrm{~m} ; 1 \mathrm{fmS}+; 3 \mathrm{st}$ ]. Sporophytes were found for the first time in the middle part of European Russia.

T. delicatulum (Hedw.) Bruch et al. - R; [17, 18, 45, 48, 58]; on rotten wood, limestones and sandstones in forests, on meadowy slope to river valley, on soil [2f; 4st].

*T. recognitum (Hedw.) Lindb. $-\mathrm{S}$; [Kaluga Distr. (Popova, 2001); 9, 19, 24, 25, 30, 33, 39, 41, 42, 47, 56, $60,61,87,90,99,106]$; open herbaceous layers: meadows, forest margins, abandoned forest road; on soil in pine and birch forests [20f; $2 \mathrm{~m} ; 1 \mathrm{fmS}+; 3 \mathrm{st}]$.

Timmia megapolitana Hedw. - R; [Kaluzhskie Zaseki Reserve (Popova, 2002); 52, 102]; in moist cave of limestone outcrop; on rotten wood near spring [2S-].

Tomentypnum nitens (Hedw.) Loeske - R; [Iznoskovsky Distr. (Rabotnov, 1929)]; small flood-plain mires.

Tortula acaulon (With.) R.H.Zander - S; [8, 17, 40, 46, $69,74,91,92,93]$; on wet bare soil in open habitats, often on molehills in meadows, arable fields [13S+].

T. modica R.H.Zander - U; [17]; slope to river valley, on limestone [1 $\mathrm{S}+]$.

T. muralis Hedw. - S; $[8,17,18,46,65,72,76,91,92$, 94]; on limestones, brick and concrete constructions [11S+; 1S-].

T. truncata (Hedw.) Mitt. - S; [8, 32, 40, 46, 72, 74, $78,87,94]$; arable and abandoned fields, roadsides; on wet bare soil [8S+].

Trematodon ambiguus (Hedw.) Hornsch. - U; Kaluga, coll. E. Nikolsky, 4.VII.1911 (LE) [S+].

Ulota crispa (Hedw.) Brid. - U; [39]; broad-leaved forest, on trunk of Tilia [1S-].

Warnstorfia exannulata (Bruch et al.) Loeske - R; [Spas-Demensky Distr. (Rabotnov, 1929), 47]; boggy bank of small river in forest, on wet peaty soil [2st].

W. fluitans (Hedw.) Loeske - S; [Kaluzhskie Zaseki Reserve, 47 (Popova, 2002); 3, 8, 20, 21, 29, 39, 51, 90, 99]; in permanent pools in depressions and old peat pits and in lakes in flood-plains [ $4 \mathrm{~S}+$ (in temporarily dried places); 6S-].

W. pseudostraminea (Müll.Hal.) Tuom. \& T.J.Kop. R; [90, 103, 110, Medynsky Distr.]; in wet unstable parts of mires and in wet bogging cuvettes [4S-].

Weissia brachycarpa (Nees \& Hornsch.) Jur. - R; [17, $46,70,75]$; slopes to river valleys, on soil [4S+].

\section{UNCONFIRMED RECORDS}

Ditrichum cylindricum (Hedw.) Grout - (Ignatov \& Ignatova, 2003).

Dicranum fuscescens Turner - (Ignatov \& Ignatova, 2003).

Philonotis tomentella Molendo - (Popova, 2001, cited unpublished data of Peshkova).

Serpoleskea confervoides (Brid.) Loeske - (Popova, 2001, cited unpublished data of Peshkova) 


\section{SOME CONSIDERATIONS ON REPRODUCTIVE} BIOLOGY OF MOSSES IN THE PROVINCE

In the moss flora of Kaluga Province, the dioicous species (including phyllodioicous) are 133 of 226 (58.8\%), while monoicous (including polyoicous) 93 (41.2\%). This ratio perfectly agrees with that of Russia as a whole $(58.3 \%)$, as well as in many other parts of the world (Ignatov et al., 2009).

The fact that many dioicous species produce sporophytes much more rarely than monoicous species is well-known. Our data just confirm this: 59 dioicous species were never found with sporophytes, in 36 species sporophytes are rare, in 18 species sporadic, and only in 11 species frequent. In the two former groups, i.e. with never or rare sporophyte production, the mixed tufts are also very rare. However in the species with more frequent sporophytes, male and female plants were commonly found nearby or growing in mixture. Mixed populations are the most common case in such a common species as Barbula unguiculata, Ceratodon purpureus, Rhizomnium punctatum, Dicranella heteromalla.

Twelve monoicous species were never found with sporophytes in the province, most of them are rare species, known by 1-2 collections only. Of the rest, 4 monoicous mosses have rare sporophyte production, 9 sporadic, and 64 frequent.

The deviations from 50:50 frequency of sexes is common in dioicous species in Kaluga Province. Among 36 dioicous species that were in a special focus of this study, 27 (77\%) have female bias, $7(17 \%)$ have about the equal frequency of sexes, and only in 2 species $(6 \%)$ male sex prevails: Anomodon viticulosus, Thuidium assimile. At the same time, among these 35 species we found none being totally sterile, and in only two species, Bryum moravicum and Leucodon sciuroides, almost all plants were sterile, with a single specimen with female gametangia. All other species have both sexes. Summing up, the absence of sporophytes in some mosses in Kaluga Province cannot be easily explained by the failure to develop one or both sexes.

Propagules or gemmae were found in Kaluga Province mostly in dioicous species: $76 \%$ of species known with propagules are dioicous.

Sporophytes were found for the first time in the middle part of European Russia for Abietinel- la abietina, Plagiomnium undulatum, Taxiphyllum wissgrillii, Thuidium assimile, and Hygroamblystegium tenax (at least, Ignatov \& Ignatova, 2003-2004 reported them without sporophytes in this area). All of them were found with sporophytes in 2008, the year that had had rather mild previous year and winter, and also very rainy summer. Summer time in 2005 and 2006 was more dry with long rainless periods.

\section{ACKNOWLEDGEMENTS}

I thank M. Ignatov \& E. Ignatova for help in identification of difficult specimens, and A. Ivanova for correcting English. The work was parly supported by RFBR, \#07-04-00013.

\section{LITERATURE CITED}

[GERASIMOV, D.A.] ГЕРАСИМОВ Д.А. 1924. Научные и практические выводы при геоботаническом исследовании торфяных болот. - [The scientific and practical conclusions on geobotanical study of pit bogs] Торфяное дело [Torphyanoe delo] [1924] (12): 1-7.

IGNATOV M.S., AFONINA O.M., IGNATOVA E.A., A. ABOLINA, T.V. AKATOVA, E. Z. BAISHEVA, L.V. BARDUNOV, E.A. BARYAKINA, O.A. BELKINA, A.G. BEZGODOV, M.A.BOYCHUK, V.YA. CHERDANTSEVA, I.V. CZERNYADJEVA, G.YA. DOROSHINA, A.P. DYACHENKO, V.E. FEDOSOV, I.L. GOLDBERG, E.I. IVANOVA, I. JUKONIENE, L. KANNUKENE, S.G. KAZANOVSKY, Z.KH. KHARZINOV, L.E. KURBATOVA, A.I.MAKSIMOV, U.K. MAMATKULOV, V. A. MANAKYAN, O.M. MASLOVSKY, M.G. NAPREENKO, T. N. OTNYUKOVA, L.YA. PARTYKA, O.YU. PISARENKO, N.N. POPOVA, G.F. RYKOVSKY, D.YA. TUBANOVA, G.V. ZHELEZNOVA, V.I. ZOLOTOV 2006 [2007]. Check-list of mosses of East Europe and North Asia. - Arctoa 15: 1-130.

IGNATOV, M.S. \& E.A. IGNATOVA] ИГНАТОВ М.C., Е.А. ИГНАТОВА 2003-2004. Флора мхов средней части Европейской России. Т. 1-2. - [Bryophyte flora of Middle Part of European Russia. Vol. 1-2] KMK, $M$. [KMK, Moscow], $960 \mathrm{pp}$.

IGNATOV M.S., E.A. IGNATOVA, O.M. AFONINA \& V.V. TELEGANOVA 2009. Moss diversity in Russia: general overview and analysis of the distribution of dioicous species. - In: Golovatch S.I., Makarova O.I., Babenko A.B. \& Penev L.D. (eds.) 2009. Species and communities in extreme environments Sofia-Moscow, Pensoft Publishers \& KMK Scientific Press. C.303-318.

[MAJOROV, S.R.] МАЙОРОВ C.P. 2001. Данные к бриофлоре Козельского района Калужской области [Data to moss flora of Kozelsky District of Kaluga province] В кн.: Флористические исследования в Центральной России на рубеже веков (Материалы совещания 29-31 янв. 2001, Рязань) (ред. В.С. Новиков и С.Р. Майоров), М., МГУ и дp. [In: V.S. Novikov \& S.R. Majorov (ed.) Floristicheskie issledovaniya $v$ Tsentralnoi Rossii na rubezhe vekov (Proc. Conf. 29-31 jan. 2001, 
Ryazan), Moskow, Mosk. State Univ. \& al.]: 87-89.

[PASHKANG, K.V. (ED.) ]ПАШКАНГ К.В. (сост.) 1989. География Калужской области, 3-е изд. с измен. [Geography of Kaluga province, 3th ed.] Тула [Tula]: 119 pp.

[PESHKOVA, G.I.] ПЕШКОВА Г.И. 1975. Материалы к бриофлоре Калужской области. Сфагновые мхи. - [Contribution to bryoflora of Kaluga province. Sphagnum mosses.] Биол. науки [Biol. nauki] 8: 66-72.

[PESHKOVA, G.I.] ПЕШКОВА Г.И. 1977. Материалы к бриофлоре Калужской области. Бриевые мхи из окр. Tapycы. - [Contribution to bryoflora of Kaluga province. Mosses from Tarusa vicinites] Биол. науки [Biol. nauki] 5: 90-93.

[POPOVA, N.N] ПОПОВА Н.Н. 2001. Материалы по бриофлоре Калужской области. - [Contribution on bryoflora of Kaluga Province] В кн.: Флористические исследования в Центральной России на рубеже веков (Материаль совещания 29-31 янв. 2001, Рязань) (ред. В.С. Новиков и С.P. Майоров), М., МГУ и др. [In: V.S. Novikov \& S.R. Majorov (ed.) Floristicheskie issledovaniya v Tsentralnoi Rossii na rubezhe vekov (Proc. Conf. 29-31 jan. 2001, Ryazan), Moskow, Mosk. State Univ. \& al.]: 110-114.

[POPOVA, N.N.] ПОПОВА Н.Н. 2002. Бриофлора Среднерусской возвышенности. - [Bryoflora of the Central Russian uppland] Arctoa 11: 101-169.

[POPOVA, N.N. \& S.I. OB'EDKOVA] ПОПОВA H.H., ОБЪЕДКОВА С.И. 2000. Предварительные данные о бриофлоре юго-восточной части национального парка «Угра» (в пределах Калужской области). - [Preliminary data of bryoflora of the southern-east part of National park
"Ugra" (in the limits of Kaluga Province)] Состояние, изучение и сохранение заповедных природных комплексов лесостепной зоны. (Сб. науч. статей, посвящ. 65-летию Хоперского государственного природного заповедника) Воронеж [Sostoyanie, izuchenie i sokhranenie zapovednykh prirodnykh kompleksov lesostepnoi zony (Sb. nauch. statei, posvyasch. 65-letiu Khoperskogo gosudarstvennogo prirodnogo zapovednica), Voronezh]: 173-176.

[RABOTNOV, T.A.] РАБОТНОВ Т.А. 1929. О болотах Калужской губернии. - [About a bogs of Kaluga Province] Торфяное дело [Torphyanoe delo] 1: 29-30.

[TELEGANOVA, V.V.] ТЕЛЕГАНОВА В.В. 2007. Новые находки мхов в Калужской области. - [New moss records from Kaluga Province] Arctoa 16: 184-186.

[TELEGANOVA, V.V. \& M.S. IGNATOV] TЕЛЕГАНОВA B.В., ИГНАТОВ М.С. 2006. Новые находки мхов в Калужской области. - [New moss records from Kaluga Province] Arctoa 15: 249-250.

[TELEGANOVA, V.V., M.S. IGNATOV \& M.A. BOYCHUK] ТЕЛЕГАНОВА В.В., М.С. ИГНАТОВ, М.А. БОЙЧУК 2008. Листостебельные мхи национального парка «Угра». - [Mosses of the national park «Ugra»] Бюллетень ГБС [Bull. Glavn. Bot. Sada] 195: 129-141.

[ZHADOVSKY, A.Е.] ЖАДОВСКИЙ А.Е. 1928. Реликтовая колония Polypodium vulgare в Калужской губернии и необходимость ее охраны. - [The relict colony of Polypodium vulgare in Kaluga province and necessity of its protection] Охрана природы [Okhrana prirody] 3: 5-13. 